\title{
EARLY DIAGNOSIS OF CRANIOSYNOSTOSIS IN INFANTS AT PRIMARY HEALTH CARE
}

\author{
Skoric Jasmina \\ Children and Youth Health Care Center "Simo Miloseviæ", Belgrade, Serbia
}

Primljen/Received 07. 09. 2014. god.

Abstract: Craniosynostosis or premature fusion of one or more cranial sutures in infants disturbs normal brain growth. This condition causes abnormal skull configuration, increased intracranial pressure, headache, strabismus, blurred vision, blindness, psychomotor retardation. The diagnosis of craniosynostosis is very simple. Pediatricians should routinely assess neurological status and measure head circumference and anterior fontanelle. When necessary, ultrasound of CNS, $\mathrm{X}$-ray and cranial CT scan can be done. When it comes to this condition, early diagnosis and surgical intervention are of utmost importance. In this paper, we have presented a case on craniosynostosis in a female infant, discovered in the third month of life during systematic review that included measurement of head circumference, palpation of anterior fontanelle and cranial sutures. The child was referred to a neurosurgeon who performed the CT scan of endocranium and confirmed the initial diagnosis of craniosynostosis. With head circumference of $40 \mathrm{~cm}$ and fused anterior fontanelle, the surgery was timely performed at the sixth month of life due to early diagnosis.

Key words: premature closure of cranial sutures, infants, early diagnosis, surgical treatment.

\section{INTRODUCTION}

Craniosynostosis or premature fusion of cranial sutures in the infant period is a serious condition that disrupts brain growth and development due to limited endocranium (1). Clinical features depend on the number of fused sutures and duration of the disorder in question. Symptoms occur as a result of pressure on the brain tissue. The most common type of craniosynostosis represents the fusion of one suture, that is, the sagittal one (2). Craniosynostosis may be primary, i.e., present at birth or in the first months of life, and secondary which is more frequent, whereby it arises as a part of numerous other syndromes (3).
Prihvaćen/Accepted 07. 10. 2014. god.

Clinical findings include an abnormal skull configuration, reduced head circumference with fused anterior fontanelle or fontanelle with reduced dimensions, increased intracranial pressure, impaired vision or blindness due to pressure on the optic nerve, psychomotor development delay, whereas epileptic seizures and other disorders are rarely identified (4).

\section{CASE PRESENTATION}

The patient is a full term female infant, born on March the $6^{\text {th }}, 2013$, to mother who had not been pregnant before. The pregnancy was normal and supervised. Normal childbirth, BM of $2950 \mathrm{~g}$, BL of $49 \mathrm{~cm}$, head circumference of $33 \mathrm{~cm}$ (above third length percentile for her age class and sex) Apgar score 9. Family anamnesis is normal.

At the first systematic review on the ninth day of life, a spontaneously resolving mild degree of jaundice was noted, whereas the other findings were normal. At the second systematic review ( 2 months and 12 days of age), protrusion of the forehead in the midline, overlapping parietal bones, dimensions of anterior fontanelle $1 \times 0.5 \mathrm{~cm}$, folds in the occipital region of the scalp, head circumference of $36.5 \mathrm{~cm}$ (third length percentile) were identified. Neurological status was normal. Child was lively and attentive with no signs of psychomotor development delay. Other findings were normal.

The child was referred to a neurologist and neurosurgeon under the suspicion of craniosynostosis. CT revealed fusion of both lambdoid sutures with overlapping parietal and occipital bones. Brain parenchyma was of the proper volume and density with no focal changes. Subarachnoid space was very constricted in the occipital region. The head had occipital flattening. On the basis of clinical findings and CT scan results, the child was diagnosed with Craniosynostosis and referred to surgical treatment. 
With the upcoming surgery, at the age of 4 months and 16 days, the attending pediatrician performed an examination. Neurological status was normal and the head circumference was $37.5 \mathrm{~cm}$, which is below the third length percentile for her age class and sex.

After the sixth month of life, the following surgery was performed: Suturectomia suturae lamdoideae billateralis. The child was admitted to the hospital with fused anterior fontanelle and head circumference of 40 $\mathrm{cm}$ which is below the third length percentile. The postoperative course was uneventful and the child was discharged home in good general condition. A pediatrician performed four more check-ups at the Health Care Center. At the age of seven months, the head circumference was $40.5 \mathrm{~cm}$, at the age of eight months was 41 $\mathrm{cm}$, at the age of 10 months was $42 \mathrm{~cm}$, at the age of 11 months was $42 \mathrm{~cm}$, still below the third length percentile for her age class and sex - see percentile growth curve of the head (Figure 1). Neurological status and psychomotor development of the child were within normal limits for the whole time. Child was being taken to regular check-ups with the neurosurgeon.

\section{DISCUSSION}

Clinical features of craniosynostosis with the fusion of one suture, and especially with the fusion of multiple cranial sutures, are very serious and therefore pediatricians should strive for early diagnosis. Treatment depends on the timing of the diagnosis and which sutures are involved. While the timing of surgery is controversial, most doctors prefer to do surgery when the child is 3-6 months old. Older children (12-18 months) with a very mild deformity will probably not need surgery, while younger children with an obvious deformity that is moderate to severe will probably benefit from early surgery $(5,6)$. In my opinion, the diag-

A

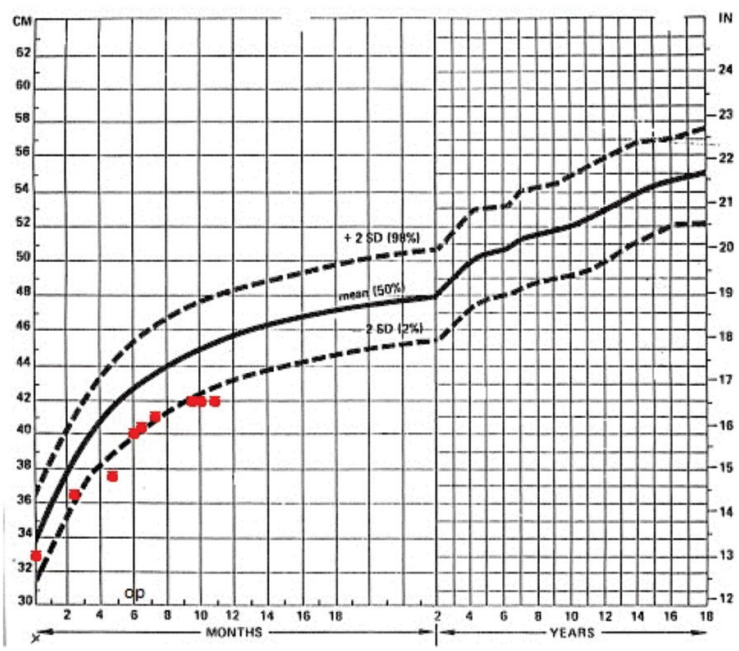

Figure 1. Infant's Head Circumference for Age Percentile Growth Chart

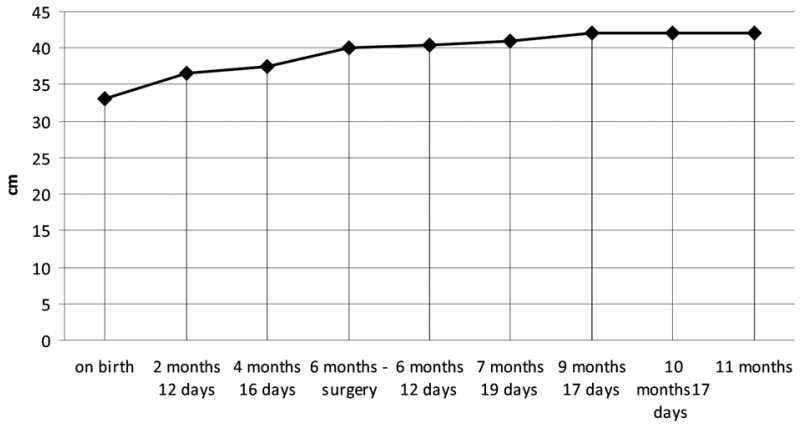

Figure 2. Head circumference growth per months

nosis can be easily set at the level of primary health care during regular medical examinations within the first months of life, or up to one year at the latest. Ultrasound of CNS as a part of prenatal diagnostics enables us to examine the condition of cranial sutures, fontanelles and brain structures at the stage of intrauterine life ( 7 , 8). As for postnatal diagnostics, regular measurement of head circumference and dimensions of anterior fontanelle, as well as palpation of the cranial sutures are simple diagnostic procedures. If the anterior fontanelle is still open, it would be advisable to perform an ultrasound of CNS due to increased intracranial pressure (9). Since changes in the retina might occur, it is desirable to do ophthalmologic examination, and possibly ENT screening (10). And finally, skull X-ray can be performed if necessary, as well as the CT scan of endocranium, as it was done in the case presented.

Although the head circumference is still below the third percentile for her age class and sex, there is an increase in head circumference by $3 \mathrm{~cm}$, with the expectation of reaching its full size in time (Figure 2).

\section{CONCLUSION}

On the basis of the case presented, we may come to a conclusion that regular health pediatric examination is one of the key components in detecting anomalies such as craniosynostosis. In this case, the condition was diagnosed at the primary health care on the basis of clinical and physical findings, and was confirmed by additional testing such as the CT scan at the level of secondary health care. The time of diagnosis, in this case the third month of life, and early surgical procedure are of utmost importance, seeing how the anomaly is quite alarming, particularly when it comes to multiple cranial fusion.
Abbreviations
CT - computerized tomography
BM - body mass
BL — body length
CNS - Central Nervous System
P3 - third percentile
ENT - Otolaryngology 


\section{Sažetak}

\section{RANA DIJAGNOSTIKA KRANIOSINOSTOZE KOD ODOJČADI U PRIMARNOJ ZDRAVSTVENOJ ZAŠTITI}

\section{Skoric Jasmina}

Dom zdravlja „Simo Miloševićc“, Služba za zdravstvenu zaštitu dece i omladine Čukarica, Beograd, Srbija

Kraniosinostoza ili prevremeno zatvaranje lobanjskih sutura kod odojčadi remeti normalan rast mozga. Ova anomalija uzrokuje abnormalnu konfiguraciju glave, povišeni intrakranijalni pritisak, glavobolje, strabizam, poremećaj vida, zastoj u psihomotornom razvoju. Dijagnostikovati kraniosinostozu je veoma jednostavno. Pedijatri bi trebalo rutinski da sprovode kontrole obima glave, neurološkog statusa, kao i merenje prednje fontanele. Ako je potrebno, takođe se može uraditi ultrazvuk CNS-a, rendgen snimak, kao i CT lobanje. Rana dijagnoza i hirurška intervencija su u ovom slučaju od najveće važnosti. Prikazan je slučaj

\section{REFERENCES}

1. Behrman RE, Kliegman RM, Jenson HB, Nelson textbook of pediatrics. $17^{\text {th }}$ ed. St. Louis, Mo: WB Saunders; 2004: 1992-1993.

2. Slater BJ, Lenton KA, Kwan MD, Gupta DM, Wan DC, Longaker MT. Cranial Sutures: A Brief Review. Plast Reconstr. Surg. 2008; 121(4): 170-8.

3. Cole P, Kaufman Y, Hollier L. Bifid Nose with Cleft Hand Deformity: Syndromic Association or Undescribed Anomaly?. J Craniofac Surg. 2008; 19(6): 1594-6.

4. Patel A, Terner J, Travieso R, Clune JE, Steinbacher D, Persing JA. On Bernard Sarnat's $100^{\text {th }}$ birthday: Pathology and Management of Craniosynostosis. J Craniofac Surg. 2012; 23(1): 105-12.

\section{Correspondence to /Autor za korespondenciju} Jasmina Škorić, MD

Address: Poručnika Spasića i Mašere 53. Belgrade 11000

Phone No: +381637128664 kraniosinostoze kod ženskog odojčeta koja je otkivena u trećem mesecu života u toku sistematskog pregleda, merenjem obima glave, palpiranjem velike fontanele i lobanjskih šavova. Dete je upućeno na hospitalizaciju sa uputnom dijagnozom kraniosinostoza, koja je potvrđena pregledom od strane neurohirurga i CT-om endokranijuma. Zahvaljujući blagovremenoj dijagnozi, urađena je operacija sa navršenih šest meseci života deteta, sa obimom glave (OG) od $40 \mathrm{~cm}$ i zatvorenom velikom fontanelom.

Ključne reči: prevremeno zatvaranje lobanjskih sutura, odojče, rana dijagnoza, hirurška terapija.

5. Bristol RE, Lekovic GP, Rekate HL. The Effects of Cranyiosinostosis on the Brain with Respect to Intracranial Pressure. Semin Pediatr. Neurol. 2004; 11 (4): 262-7.

6. Cunningham ML, Heike CL. Evaluation of the Infant with an Abnormal Skull Shape. Curr Opin Pediatr. 2007; 19 (6): 645-51.

7. Lenton KA, Nacamuli RP, Wan DC, Helms JA, Longaker MT. Cranial Suture Biology. Curr Top Dev Biol. 2005; 66: 287-328.

8. Lattanzi W, Bukvic N, Barba M, et al. Genetic Basis of Single-suture Synostosis: genes, chromosomes, and clinical implications. Child's Nerv Syst. 2012; 28(9): 1301-10.

9. Rice DP. Clinical Features of Syndromic Craniosynostosis. Front Oral Biol 2008; 12: 91-106.

10. Wiegant C, Richards P. Measurement of Intracranial Pressure in Children: A Critical Review of Current Methods. Dev Med Child Neurol. 2007; 49 (12): 935-41. 